sert for 40 år siden, er ikke tilsvarende lett tilgjengelig (2). Data fra undersøkelsene gir mulighet til vurdering av trender i et 45 års tidsperspektiv ved samme avdeling.

Den siste undersøkelsen er et tiårsmateriale som bare omfatter infeksiøs endokarditt. Min undersøkelse omfatter alle tilfeller av sepsis, med infeksiøs endokarditt som undergruppe i et femårsmateriale fra årene 1964-68. Relevante data fra endokardittmaterialet blir gjengitt her.

Hele sepsismaterialet utgjorde 51 pasienter, dvs. vel ti pasienter per år i snitt. Samlet mortalitet var $27 \%$ (2). Av de 51 fikk ti diagnosen endokarditt. Bare én av disse døde, dvs. 10\% mortalitet (2). Min undersøkelse ble planlagt i 1966 og var derfor både retrospektiv og prospektiv. Jeg mener den gir et pålitelig tidsbilde av hvordan denne pasientgruppen ble behandlet for over 40 år siden.

Kliniske data og sammensetning i de to undersøkelsene viser ikke store forskjeller, men insidensen ser ut til å ha økt fra to til 6,3 per år $(1,2)$. Mortaliteten var i mitt materiale $10 \%$, i det siste $16 \%$. Prinsippene for valg av antibiotika etter resistens og behandlingslengden var like. Dette viser at infeksjonsbehandling var godt etablert. Derimot var mulighetene for kardiologiske spesialundersøkelser sterkt begrenset. Transøsofageal ekkokardiografi hadde sannsynligvis ført til at noen i mitt materiale med klassifikasjonen sepsis ville ha fått diagnosen endokarditt. Det ville gitt økt årlig insidens og høyere mortalitet i mitt materiale. Men etter min mening ville det neppe gitt så store utslag at det ville ha svekket inntrykket av at insidensen av endokarditt har vært økende.

Det indremedisinske fagområdet har forandret seg enormt fra jeg var ferdig lege i 1960. Enkelte fra min generasjon og atskillig flere av de yngre har periodevis tendens til å nedvurdere det man kunne gjøre før 1970. Disse to undersøkelsene gir ikke grunnlag for en slik nedvurdering. Verdien av det tradisjonelle kliniske skjønnet på basis av gode kunnskaper og en fullstendig klinisk undersøkelse bør ikke avskrives.

\section{Odd Johan Frisvold}

ojofrisv@online.no

Ålesund

Ole Johan Frisvold (f. 1934) er spesialist i indremedisin og hjertesykdommer og er pensjonert avdelingsoverlege, Medisinsk avdeling og sjeflege Sentralsjukehuset i Møre og Romsdal. Ingen oppgitte interessekonflikter.

\footnotetext{
Litteratur

1. Gulati G, Hole T, Eide E. Infeksiøs endokarditt ved Ålesund sjukehus 1997-2006. Tidsskr Nor Legeforen 2011; 131: 115-7.

2. Frisvold OJ. Sepsis. Tidsskr Nor Lægeforen 1970; 90: $1697-700$
}

Hole og medarbeidere svarer:

Vi takker for interessen for vår artikkel. Ved litteraturs $\varnothing \mathrm{k}$ fant vi dessverre ingen referanse til Frisvolds artikkel (1), sannsynligvis fordi dette hovedsakelig er kategorisert som et sepsismateriale.

Den økte insidensen av infeksiøs endokarditt i vår studie (2) kan til en viss grad, som Frisvold påpeker, skyldes økt sensitivitet til å påvise vegetasjoner ved bruken av transøsofageal ekkokardiografi. Det er nærliggende å tro at de standardiserte Dukes' kriterer fra 1994 øker presiseringen av diagnostiseringen for infeksiøs endokarditt. Om insidensen er økende, er derfor vanskelig å si. Riktignok har vi i dag en mindre gruppe med revmatisk klaffelidelse i befolkningen, men pasientgruppen som rammes er blitt eldre, og agens er endret. Mange har også intravaskulære/intrakardiale implantater. Antibiotika brukes etter resistensmønster, og resistensmønsteret har endret seg. I Frisvolds artikkel var det kun $8 \%$ penicillinresistente gule stafylokokker i Norge, i dag er det ca. $80 \%$. Den gang ble streptomycin brukt hyppig, og antibiotika ble ofte gitt intramuskulært. Streptomycin og intramuskulær administrering er ute av den kliniske hverdagen i dag.

Mortaliteten i Frisvolds materiale var på $10 \%$, i vårt materiale var dette på $16 \%$. Det er usikkert om økt diagnostisering av infeksiøs endokarditt i Frisvolds materiale ville ført til økt mortalitet hos denne gruppen. I hans materiale hadde ni av ti med diagnosen endokarditt oppvekst av grampositive agens. I totalmaterialet hadde 25 av 51 pasienter oppvekst av grampositive agens, og av disse var det ti som hadde grønne streptokokker og sju som hadde gule stafylokokker. I vårt materiale var det overvekt av grampositive agens, hovedsakelig stafylokokker og da spesielt gule stafylokokker som er mer virulente enn streptokokker. Skifte av agens kan forklares av endret pasientgruppe, og endret agens kan også eventuelt forklare et mer virulent forløp.

Kunnskapen innenfor medisinen er under stadig utvikling, og hva som en gang ble ansett som riktig behandling kan i dag være kontraindisert ved samme sykdom. Vi er enige i verdien av det kliniske skjønn på basis av gode kunnskaper. En fullstendig klinisk undersøkelse bør ikke avskrives, men den bør kombineres med maksimal utnyttelse av moderne teknologi og nye kunnskaper.

\section{Torstein Hole}

torstein.hole@helse-sunnmore.no Geeta Gulati

Eigill Eide

Medisinsk avdeling

Ålesund sjukehus
Torstein Hole (f. 1957) er dr.med. og spesialist i indremedisin og i hjertesykdommer. Han er klinikksjef ved Medisinsk klinikk, Helse Sunnmøre og amanuensis II, Det medisinske fakultet, NTNU. Ingen oppgitte interessekonflikter.

Geeta Gulati (f. 1982) er cand.med., stipendiat, arbeidet ved Medisinsk avdeling, Ålesund sjukehus, er nå ved Akershus universitetssykehus. Ingen oppgitte interessekonflikter.

Eigill Eide (f. 1947) er spesialist i infeksjonssykdommer og er avdelingsoverlege, Medisinsk avdeling. Ingen oppgitte interessekonflikter.

Litteratur

1. Frisvold OJ. Sepsis. Tidsskr Nor Lægeforen 1970; 90: 1697-700

2. Gulati G, Hole T, Eide E. Infeksiøs endokarditt ved Ålesund sjukehus 1997-2006. Tidsskr Nor Legeforen 2011: 131: 115-7.

\section{RETTELSE}

Infeksiøs endokarditt ved Ålesund sjukehus 1997-2006.

Geeta Gulati, Torstein Hole, Eigill Eide

Tidsskr Nor Legeforen 2011; 131: 1154-7

I Tidsskriftet nr. 2, side 117, tabell 4: Enterobacter cloacae var feilaktig plassert i gruppen enterokokker, skulle vært plassert under gruppen Annet.

\section{Tilsvarsrett:}

Tidsskriftet praktiserer tilsvarsrett i henhold til Vancouver-gruppens regler (www.icmje.org/publishing 5 correspond.html).

Dette innebærer at forfattere av vitenskapelige artikler som blir kommentert i spalten Brev til redaktøren, får anledning til å komme med tilsvar i samme nummer av Tidsskriftet. Ytterligere innlegg vil bli henvist til et senere nummer. 